International Journal of Social Science And Human Research

ISSN(print): 2644-0679, ISSN(online): 2644-0695

Volume 04 Issue 12 December 2021

DOI: $10.47191 / \mathrm{ijsshr} / \mathrm{v} 4-\mathrm{i} 12-77$, Impact factor-5.586

Page No: 3995-3997

\title{
Semantic Classification of Adverbial Phraseological Units of the Russian Language
}

\author{
Sabina Y. Yuldasheva \\ Master Student, Kokand State Pedagogical Institute, Uzbekistan
}

ABSTRACT: In the article, the author makes an attempt to semantic classification of adverbial phraseological units of the Russian language by applying the method of component analysis.

KEYWORDS: adverbial phraseological units, sememe, phraseme, lexeme, expression plan, content plan, denotative meaning, semantic component, stylistic seme, evaluative seme.

\section{INTRODUCTION}

Adverbial phraseological units of the Russian language require additional study, since the overwhelming majority of articles, dissertations; monographs are devoted to verbal and substantive phraseology, although quantitatively adverbial phraseological units are second only to verbal ones. So, according to our calculations, the "Phraseological Dictionary of the Russian Language" edited by A. I. Molotkov contains about 1400 idiomatic and reproducible units of an adverbial character, that is, more than 1/3 of their total number. The consequence of insufficient attention of linguists to adverbial phraseology is the frequent inclusion of adverbial phraseological units in the verb. First of all, this applies to units of the Russian language with accompanying words: $v$ tri ruchya (to cry), do sedmova pota (to work), na tvoy shkure (to test), slomya golovu (to run away). Similar formations make up about $40 \%$ of adverbial phraseology.

The available articles and monographs testify to successful attempts to study the semantics of APU (adverbial phraseological units) of the Russian language by various methods and techniques. In them, APU is investigated not only in the field of the Russian language, but also in comparison with the phraseological systems of other languages, belonging mainly to the IndoEuropean family. Moreover, if in early works the semantic groups distinguished among APU were established, as a rule, on the basis of the semantic categories of adverbial lexemes (L.V. Orlova, A.V. Zhukov, A.I. Molotkov, O.P. Ivanova, A. D. Zinkov and others), then in later works these units are already considered as part of a specific PSG (phraseological-semantic group), where they constitute its significant part: "degree", "time", "quantity", "Limit" (L.A. Mizyaeva, S.V. Stolbunova, R.A. Semergei, S.I. Kravtsova, B. Shtefan, etc.).

\section{THE MAIN FINDINGS AND RESULTS}

Special attention should be paid to the dissertation of K.T. Mirzaeva. In her research, the study of the syntagmatic properties of the phraseological units (PU) under consideration is carried out on the material of the Russian language. By the nature of the meaning, it divides phraseological units with qualitatively adverbial semantics into the following groups: 1) with the meaning of the course of action; 2) with the value of the actual qualitative characteristics of the action (state); 3) with a meaning characterizing the emotional attitude to the performed action. Each of the named groups is divided, in turn, into subgroups, united by a common element of meaning. Within each of them, the structural types of phraseological units are determined $[1,16]$.

An analysis of the literature on this problem showed that from the point of view of semantics, APU in the Russian language in its entirety and integrity has not been studied enough.

In our opinion, the study of certain semantic groups united by a common meaning is relevant. The purpose of our research in this article is, based on the achievements and accumulated experience of linguists dealing with phraseological semantics, by using the method of component analysis to expand and deepen the semantic classification of APU based on the facts of the Russian language.

PU, like lexical units, also have two closely interrelated sides: the content plan and the expression plan, i.e. have a sound complex and phraseological meaning proper, which are designated as phraseme (or simply phraseme) and sememe.

It should be borne in mind that the second concept is more complex, even if we are dealing only with an unambiguous unit, since in its composition, in addition to the semantic component itself (denotative meaning), there may be other, additional meanings: 


\section{Semantic Classification of Adverbial Phraseological Units of the Russian Language}

stylistic seme, evaluative seme and etc. When studying the APU of the Russian language, we, as a rule, proceed from the first component - the actual meaning of the phraseological unit.

APU, as vocabulary units of a language, have much in common with the words that identify them. But a careful comparison of the meanings expressed by them will reveal that they also have significant differences. Such a distinctive feature is that in the semantic structure of APU, as it were, two semes coexist, one of which is a carrier of material, material meaning, and the other only expresses an additional, additional shade of meaning such as: "very", "completely", "absolutely", "too", "finally", "extremely", which can only indicate the highest, extreme degree of the manifested feature, the action inherent in its main meaningful seme. Let's compare: quickly (normal) - vo vse lopotki / slomya golovu (very fast) or a little (normal) - kot naplakal/s gulkin nos (very little).

From the point of view of the internal content of phraseological units belonging to the category of adverbial ones, as a rule, consist of at least three elements: seme of material content, categorical seme, reinforcing seme. Moreover, the latter only enhances the meaning expressed by this phraseological unit, contained in its material content seme, which also performs a semantic distinctive function, and the amplifying seme serves for the generalized name of this phraseological and grammatical category. For example, such APU: "cherez pen kolodu, ispokon vekov, po-tshuchemu veleniyu, veroy i pravdoy, na ves narod, do poteri soznaniyai" among many others - an intensifying shade of meaning is not particularly noted in phraseological dictionaries. But if you take a closer look at their semantic structure, you will find that in these phraseological units there is an amplifying seme. In the semantic classification of APU, we rely only on the seme of material meaning, since only it carries semantic distinctive features that make it possible to distinguish the phraseological unit, in the semantic structure of which it participates, from other units of the class under consideration.

However, the quantitative composition of semes in the semantic structure of APU is not limited to the above-considered elementary units of meanings. Within one sememe, there are also semes that allow them to be grouped into PSG, subgroups and microgroups. For example, in units like: kak svoi pyat paltsev; kak na korove sedlo; vo vse glaza; kraem glaza; ne za strax, a za sovest; cherez pen kolodu; kak ptisa nebesnaya; ne $k$ shube rukavi - there is such an element of meaning that allows them to be combined into one group, although each of the AFUs presented has a differential seme characteristic only of it: "good", "bad", "attentively", "inattentively", "carefully", "carelessly", "arranged", "unsettled", etc. Consolidation in the PSG, therefore, is carried out at a fairly general level.

By PSG, we mean such a union of APU, which is subsumed under some archiseme, enclosed in one way or another in each of the units assigned to it. In total, we distinguish 8 PSGs with a seme of real meaning, each of which has a common name with the category that is customary to denote adverbial lexemes $[2,67]$. When assigning APU according to semantic groups, a significant role is assigned to its dictionary definition; in part, questions that have a categorical feature are also used (for example: when? Since when? - with a temporal meaning; where, from where? - with a spatial meaning, etc.).

At the next stage of the semantic classification of the APU of the studied languages, the meanings of a narrower range of units are detailed on the basis of the allocation of a less abstract seme (macroseme) separately in each of the previously established PSGs.

APU with the macro-element "proper quality", in turn, depending on the semantics expressed by them, can be represented as an opposition of two specific semantic real meanings: "good" - "bad" (kak nado-Bod znaet kak). However, not all phraseological units of the type under consideration can be summed up under this opposition. There is also such APUs that expresses relations that are neutral from the point of view of a qualitative assessment of the action: seredina na polovinu, ni shatka ni valko, tak sebe and etc.

The semantic classification of the APU of the Russian language is built according to the following scheme: a border is drawn between the phraseological parts of speech, as a result of which the quantitative composition of the APU is established; amplifying phraseological units are delimited, as a result of which only units remain in the research field, which express the real value; the latter, by identifying the seed composition, are combined into 8 PSGs based on the archiseme, which at this stage has a high degree of abstraction; at the second stage, each FSH is delimited into separate subgroups based on the macroseme, which therefore has a large number of semantic features; at the third stage, within each subgroup, such types of APU are distinguished, which have a common seme of material meaning (the seme of the third degree); each seme of the third degree, as a rule, is built on the opposition of the meanings of two specific semes of material meaning (seme of the fourth degree); in the subgroups identified on the basis of semes of material meaning (seme-3 and seme-4), APUs are established that are in synonymous and antonymic relations, synonymous-antonymic series are determined.

\section{CONCLUSION}

Thus, the study of the semantics of phraseological units requires a multifaceted, comprehensive approach, since its content side is hidden from direct observation; moreover, their general integral meaning is not motivated by its constituent components, and the categorical meaning of phraseological units quite often does not correspond to the external grammatical form. All this, of course, makes it difficult to assimilate them not only for representatives of other nationalities, but also for the native speakers themselves. 


\section{Semantic Classification of Adverbial Phraseological Units of the Russian Language}

The study of the semantic side of phraseological units requires knowledge of the features of their structural and semantic organization.

\section{REFERENCES}

1) Mirzaeva K.T. (1985) Phraseological units with qualitative-adverbial meaning in Russian and their Uzbek equivalents. Abstract of the thesis. Dis. Candidate of Philological Sciences. - Moscow. - p. 16.

2) N. V. Tsvetkov. (1984) To the methodology of component analysis. In the journal: "Questions of Linguistics". - p. 67. 